\title{
THE INFLUENCE OF SERVICES, FACILITIES AND LOCATIONS TO PURCHASING DECISIONS AND CUSTOMER SATISFACTION ON WARKOP DEWA SIDOARJO
}

\author{
Dewi Setyoningrat $^{1}$, I Gede Arimbawa ${ }^{2}$, Elok Damayanti ${ }^{3}$ \\ setyoningratdewi0903@gmail.com¹, gede.arimbawa@ narotama.ac.id², elok.damayanti@ narotama.ac.id ${ }^{3}$ \\ Departement of Management, Faculty of Economy and Business, Narotama University \\ J1 Arief Rahman Hakim 51, Surabaya, Indonesia 60117 1,2,3
}

\begin{abstract}
The purpose of this study was to analyze the influence of service, facilities, and location on purchasing decisions and customer satisfaction. Type of research is quantitive. The population of this study was 100 respondents who visited warkop Dewa Sidoarjo . The analysis technique used Partial Least Square (PLS). Data obtained from questionnaires and tested with SmartPLS 3.0 application. The results of this study indicate that services, facilities and locations have a positive and significant influence on purchasing decisions and customer satisfaction. Purchasing decisions have a positive and significant influence on customer satisfaction.
\end{abstract}

Keywords: : Services, Facilities, Locations, Purchasing Decisions, Customer Satisfaction.

\section{INTRODUCTION}

Customer satisfaction is a feeling of pleasure or disappointment that someone appears after comparing the performance of product results that are thought of the expected performance (Kotler dan Keller, 2009). In order to be able to survive in the business world, the company must be able to improve its marketing strategy to keep its customers, one of which is the company must meet the needs and desires of customers, for example by providing promotional programs. One special feature of customer satisfaction is those who make regular and repeated purchases. The process to reach the level of customer satisfaction begins when the customer evaluates the product or service, and certain programs offered by the company so that the customer has specific experience about purchasing decisions. Another thing that is not less important is the situational factor of the customer's attitude that also influences the behavior of purchasing decisions so that it is easy to move to competitors' products or services.

The focus of this research is on Dewa Warkop in Sidoarjo which is in a strategic and easily accessible area, namely in Jl. Imam Bonjol no.12 Galuran Taman Sepanjang Sidoarjo. Warkop Dewa is a culinary venture that carries a concept of simple stalls, coffee shops and hangouts for all walks of life.

\section{LITERATURE REVIEW}

\section{Services (X1)}

Service is all activities needed to receive, process, deliver and fulfill customer orders and to follow up on any activities that contain errors (Payne, 2008). Service is selling behavior to buyers by giving satisfaction to consumers or buyers, so that buyers feel valued and can get goods or services in accordance with the wishes of the buyer (J. Paul Peter Jery C Olson, 2005). customer service is an activity throughout the business area that seeks to combine sales services to meet customer satisfaction ranging from ordering, processing to providing results of services through communication to accelerate cooperation with consumers. 
This research explores the effect of Services variables on Purchasing Decisions and customer satisfaction, using the service indicators proposed by (Sumadi, 2001) namely: direct evidence, reliability, responsiveness, assurance, empathy.

Hypothesis 1 : service has a significant effect on purchasing decisions

The better services provided to consumers, the higher the level of consumer purchasing decisions.

Hypothesis 2 : Service has a significant effect on customer satisfaction

The better service provided to consumers, the higher the level of satisfaction of consumers after coming and buying at Warkop Dewa

\section{Facilities (X2)}

Facilities are the provision of physical equipment to provide convenience to guests in carrying out activities, so that the needs of visitors can be fulfilled during activities (Sulastiyono, 2011). A facility is a physical facility that can process an input towards the desired output (Moekijat, 2001). Facilities are all things that provide convenience to consumers in business that are engaged in services, therefore many aspects that must be considered by business owners ranging from complete facilities, interior and exterior design and facility distress(Sulastiyono, 2011).

This study examines facility variables against purchasing decisions and customer satisfaction through facility indicators according to (Lalu, 2003) namely:

1. completeness, cleanliness, and neatness of the facilities offered

2. Conditions and functions of facilities offered

3. Ease in using the facilities offered

Hypothesis 3 : facilities have a significant effect on purchasing decisions

The more and complete facilities available to consumers, the higher the level of consumer purchasing decisions.

Hypothesis 4 : Facilities have a significant effect on customer satisfaction

The more and complete facilities available to consumers, the higher the level of consumer satisfaction.

\section{Location (X3)}

Location is a place where companies operate and where companies are conducting activities to produce goods or services that are of economic importance (Tjiptono, 2002). Location is a place to carry out a business and is a crucial factor for the success or failure of a business (Tjiptono, 2008).

Research examines location variables on purchasing decisions and customer satisfaction using location indicators according to (Kotler dan Keller, 2009) are as follows: Access, visibility, wide parking area, expansion, traffic.

Hypothesis 5 : Location has a significant effect on purchasing decisions

A strategic and easily accessible location will improve the behavior of consumers to decide to make purchases in Warkop dewa.

Hypothesis 6 : Location has a significant effect on customer satisfaction

A strategic location and easy to reach will create satisfaction with customers.

\section{Purchasing Decisions (Y1)}

Consumer decision making is a process of integration that combines knowledge to evaluate two or more alternative behaviors and choose one of them (Peter, 1999). Purchasing behavior is a process of decisions and actions of someone involved in the use and purchase of products (Engel, James F,. Blackwell, R.D. \& Miniard, 1995). The purchase decision is the stage of the decision process where the consumer actually purchases the product (Kotler, 2003) This study uses indicators of purchasing decisions proposed by (Kotler, 1995) namely :

1. Stability on a productKebiasan dalam membeli

2. Give recommendations to others

3. Make a repeat purchase 
Hypothesis 7: purchasing decisions have a significant effect on customer satisfaction

The more consumers who decide to visit and buy at Dewa Sidoarjo Warkop, the higher the level of satisfaction obtained by these consumers.

Customer Satisfaction (Y2)

customer satisfaction is a feeling of pleasure or disappointment that someone who appears after comparing the performance of product results that are thought of the expected performance (Kotler dan Keller, 2009). Consumer satisfaction is the result felt by buyers who experience the performance of a company that matches their expectations (Kotler, 2000). This study uses indicators of customer satisfaction according to (Tjiptono, 2005) : Confirmation of expectation, Repurchase interest. And according to (Pratiwi, 2010) : No complaints about the product, customer satisfaction in the whole product.

\section{Research Framework}

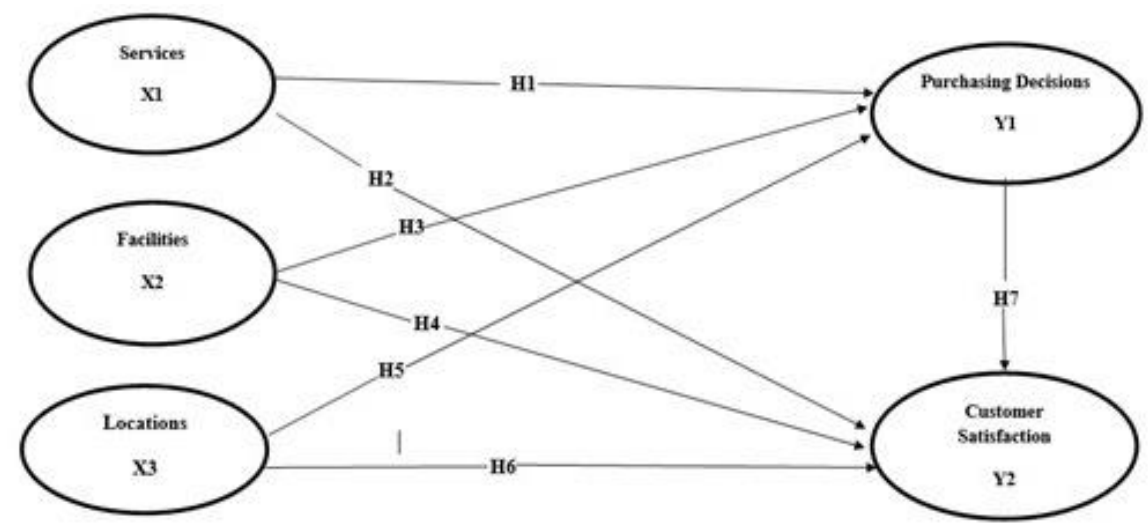

Figure 1: Research Framework

\section{METODOLOGY}

Research uses a quantitative approach is a method based on the philosophy of positivism, used to examine the population or a particular sample, data collection using research instruments, data analysis is quantitative / statistical, with the aim of testing predetermined (Prof. Dr sugiyono, 2008). This research variable consists of independent variables of service, facilities and location. Intervening variables are purchasing decisions. And the dependent variable is Customer satisfaction. The population in this study were customers who came and bought at Warkop Dewa Sidoarjo, as many as 100 respondents. The data analysis technique uses Partial Least Square (PLS) with SmartPLS 3 software.

\section{RESULT AND DISCUSSION}

The R-Adjusted impulse buying behavior variable of 0.769 shows that the independent variables of service, facilities, and location contribute $76.9 \%$ to purchasing decisions and the remaining $23.1 \%$ is influenced by other factors, while the R-Adjusted customer satisfaction variable is 0.843. that the independent variables of service, facilities and location contribute $84.3 \%$ and the remaining $15.7 \%$ is influenced by other factors.

In testing the hypothesis, a data must meet a criterion, and the hypothesis is said to be accepted if the $\mathrm{t}$-statistic value is greater than t-table and if the p-value is less than 0.05 and vice versa.

The output of the SmartPLS is as follows:

Tabel 1 : Path Coefficient

\begin{tabular}{|l|l|l|} 
Path Coefficient & t-statistic & p-value \\
\hline
\end{tabular}




\begin{tabular}{|l|c|c|}
\hline Services (X1) -> Purchasing Decisions (Y1) & 2.499 & 0.006 \\
Services (X1) -> Customer Satisfaction (Y2) & 3.877 & 0.000 \\
Facilities (X2) -> Purchasing Decisions (Y1) & 2.869 & 0.002 \\
Facilities (X2) -> Customer Satisfaction (Y2) & 3.148 & 0.001 \\
Location (X3) -> Purchasing Decisions (Y1) & 2.803 & 0.003 \\
Location (X3) -> Customer Satisfaction (Y2) & 1.970 & 0.025 \\
Purchasing Decisions (Y1) -> Customer Satisfaction (Y2) & 2.006 & 0.023 \\
Services $\rightarrow$ Purchasing Decisions $\rightarrow$ Customer Satisfaction & 1.773 & 0.038 \\
Facilities $\rightarrow$ Purchasing Decisions $\rightarrow$ Customer Satisfaction & 1.528 & 0.064 \\
Location $\rightarrow$ Purchasing Decisions $\rightarrow$ Customer Satisfaction & 1.528 & 0.064 \\
\hline
\end{tabular}

Source, output SmartPLS 3.0, 2019

\section{Direct influence \\ Hypothesis 1 : service has a significant effect on purchasing decisions}

Based on the results of the analysis it can be seen that the service has a positive and significant effect on purchasing decisions with the results of $\mathrm{p}$-value $0.006<0.050$ and $\mathrm{t}$-staistic value $>\mathrm{t}$-table which is $2.499>1.661$.

The results of this study are supported by previous research conducted by (Wanda, 2015) entitled the influence of price and service on purchasing decisions at Lulu Mart Samarinda Mini Market shows that the service variable has a significant influence on purchasing decisions at Lulu Mart Samarinda. This shows that by providing good service to consumers, the consumer will make a decision to buy and hang out at Warkop Dewa Sidoarjo

Hypothesis 2 : Service has a significant effect on customer satisfaction

Based on the results of the analysis, it can be seen that the service has a positive and significant effect on customer satisfaction with the results of p-value $0.000<0.050$ and t-staistik $>\mathrm{t}$-table which is $3.877>1.661$.

This research is supported by research conducted by (Firdiyansah, 2017) with the research title Effect of Service Quality, Price and Location on Customer Satisfaction at Warung Gubrak Kepri mall Batam city, shows that location has a significant effect on customer satisfaction. This shows that with the existence of a strategic location and easy to reach it will create a level of customer satisfaction after coming and buying in Warkop Dewa Sidoarjo.

Hypothesis 3 facilities have a significant effect on purchasing decisions

Based on the results of the analysis, it can be seen that the facility has a positive and significant effect on purchasing decisions with the results of p-value $0.002<0.050$ and $\mathrm{t}$-staistic value $>\mathrm{t}$-table which is $2.869>1.661$.

This research is supported by research conducted by (Nicklouse. Christian Lempoy, 2015) with the research title The Effect of Price, Location and Facilities on Decisions Using Tourism Park Toar Lumimuut (Taman Eman) Sonder, shows that facilities have a significant effect on purchasing decisions. This shows that with the more and complete facilities provided, the higher the level of the customer's decision to come or buy in warkop Dewa Sidoarjo.

Hypothesis 4 facilities have a significant effect on customer satisfaction

Based on the results of the analysis it can be seen that the facility has a positive and significant effect on customer satisfaction with the results of p-value $0.001<0.050$ and t-staistik $>$ t-table which is $3.148>1.661$.

This research is supported by research conducted by (Toriq, Mochammad dan Martoatmodjo, 2014) dwith the title Effect of Facilities and Service Quality on Customer Satisfaction At Pertamina Gas Station in Sidoarjo states that facilities have a significant effect on customer satisfaction. This shows that the easier and more complete facilities provided by Warkop Dewa are the higher the level of customer satisfaction after coming and buy in Warkop Dewa Sidoarjo. 
Hypothesis 5 Location has a significant effect on purchasing decisions

Based on the results of the analysis it can be seen that the location has a positive and significant effect on purchasing decisions with the results of $\mathrm{p}$-value $0.003<0.050$ and $\mathrm{t}$-staistik $>\mathrm{t}$-table which is $2.803>1.661$.

This research is supported by research conducted by (Nicklouse. Christian Lempoy, 2015) with the research title The Effect of Price, Location and Facilities on Decisions Using Tourism Park Services Toar Lumimuut (Taman Eman) Sonder, shows that location has a significant effect on purchasing decisions. This shows that a warkop that has a strategic location and is easy to reach will be better able to improve consumer behavior to decide to come and buy at Warkop Dewa

Hypothesis 6 Location has a significant effect on customer satisfaction

Based on the results of the analysis, it can be seen that the location has a positive and significant effect on customer satisfaction with the results of $\mathrm{p}$-value $0.025<0.050$ and $\mathrm{t}$-staistik $>\mathrm{t}$-table which is $1970>1,661$.

This research is supported by research conducted by Firdiyansah, (2017) ith the research title Effect of Service Quality, Price and Location on Customer Satisfaction atWarung Gubrak Kepri mall Batam city, shows that location has a significant effect on customer satisfaction. This shows that with the existence of a strategic location and easy to reach it will create a level of customer satisfaction after coming and buying in Warkop Dewa Sidoarjo.

Hypothesis 7 purchasing decisions have a significant effect on customer satisfaction

Based on the results of the analysis it can be seen that purchasing decisions have a positive and significant effect on customer satisfaction with the results of $\mathrm{p}$-value $0.023<0.050$ and $\mathrm{t}$-staistik $>\mathrm{t}$ table which is $2006>1,661$.

This research is supported by research conducted by (Santoso, 2016) dengan judul peran kualitas dan layanan, harga dan atmosfer rumah makan cepat saji terhadap keputusan pembelian dan kepuasan konsumen, menyatakan bahwa Keputusan pembelian memiliki pengaruh yang signifikan terhadap kepuasan pelanggan. Hal ini menunjukkan bahwa semakin banyak konsumen yang menutuskan untuk datang mengunjungi dan membeli di warkop dewa Sidoarjo maka akan semakin tinggi tingkat kepuasan konsumen tersebut

\section{Indirect Effects \\ Service (X1) to Customer Satisfaction (Y2) through a Purchase Decision (Y1)}

The results of this study indicate that service has a positive and significant effect indirectly to customer satisfaction through purchasing decisions. This is because the p-value of $0.044<0.050$ and t-statistics> t-table 1.714> 1,661. This shows that the better the service provided to consumers, the higher the level of the customer's decision to come and buy in the god's warkop and increase satisfaction consumers who have visited Warkop Dewa Sidoarjo.

Facility (X2) to Customer Satisfaction (Y2) Through Purchasing Decisions (Y1)

The results of this study indicate that Facility have a positive and significant effect indirectly to customer satisfaction through purchasing decisions. This is because p-value $0.043>0.050$ and $\mathrm{t}$ statistics <t-table $1,716<1,661$.

This shows that with more and more complete facilities provided, the higher levels of the customer decision to come or buy in Dewa Sidoarjo warkop and will increase the satisfaction of consumers who have visited Warkop Dewa Sidoarjo.

Location (X3) to Customer Satisfaction (Y2) Through Purchasing Decisions (Y1)

The results of this study indicate that the location has a positive and significant influence indirectly through purchasing decisions.

This is because the $\mathrm{p}$-value is $0.081>0.050$ and t-statistics $<\mathrm{t}$-table $1.398<1.661$.This shows that customers intend to visit and buy in warkop Dewa Sidoarjo because access to get there is considered to be easy to go through and you want even though Dewa Warkop does not provide extensive parking spaces. 


\section{CONCLUSION}

The findings of this study indicate that the direct influence of the independent variables of service, facilities and location has a positive and significant effect on purchasing decisions and customer satisfaction on Warkop Dewa Sidoarjo customers.

For service and facilities variables, it has a positive and significant indirect effect on customer satisfaction through purchasing decisions. And the faction variables have a positive and insignificant effect indirectly on customer satisfaction through purchasing decisions.

\section{REFERENCES}

Engel, James F,. Blackwell, R.D. \& Miniard, P. W. (1995). Perilaku Konsumen Jilid 1 (Enam). Jakarta: Bina Rupa Aksara.

Firdiyansah, I. (2017). PENGARUH KUALITAS PELAYANAN, HARGA, DAN LOKASI TERHADAP KEPUASAN PELANGGAN PADA WARUNG GUBRAK KEPRI MALL KOTA BATAM, 1-9.

J. Paul Peter Jery C Olson. (2005). Perilaku Konsumen dan Strategi Pemasaran (Edisi 4 Ji). Jakarta: Erlangga.

Kotler dan Keller. (2009). Manajemen Pemasaran. Jilid I. (Ke 13). Jakarta: Erlangga.

Kotler, P. (1995). Manajemen Pemasaran. Jakarta: Erlangga.

Kotler, P. (2000). Manajemen Pemasaran : Analisis Perencanaan Implementasi dan Pengendalian Jilid II. Jakarta: Prenhallindo, Jakar.

Kotler, P. (2003). Manajemen Pemasaran Jilid 1 dan Jilid 2 (ke Sebelas). Jakarta: PT. Indeks.

Lalu, S. (2003). Dasar-dasar Nanajemen Produksi dan Operasi. Jakarta: Salemba Empat.

Moekijat. (2001). Manajemen Personalia dan Sumber Daya Manusia. Jakarta: pustaka.

Nicklouse. Christian Lempoy. (2015). Pengaruh Harga, Lokasi dan Fasilitas Terhadap Keputusan menggunakan Jasa Taman Wisata Toar Lummuut (Taman Eman) Sonder. EMBA, 3.

Payne, A. (2008). Pemasaran Jasa (Pertama, C). Yogyakarta: Andi.

Peter, J. P. \& J. C. O. (1999). Consumer Behaviour, Perilaku Konsumen \& Strategi Pemasaran. Jilid $1 \& 2$ (ke 4). Erlangga.

Pratiwi, D. I. (2010). "Analisis Pengaruh Harapan Pelanggan, Kualitas Produk, dan Kepuasan Pelanggan Terhadap Loyalitas Pelanggan Internet Flash Unlimited di Semarang. Retrieved from https://core.ac.uk/download/files/379/11722037.pdf

Prof. Dr sugiyono. (2008). Metode Penelitian Kuantitatif Kualitatif Dan R\&D. Bandung: Alfabeta, Bandung.

Santoso, I. (2016). Peran Kualitas Produk dan Layanan , Harga dan Atmosfer Rumah Makan Cepat Saji terhadap Keputusan Pembelian dan Kepuasan Konsumen, 15(1), 94-109.

Sulastiyono. (2011). Manajemen Penyelenggara Hotel. Bandung: Alfabeta.

Sumadi. (2001). Konsep dan Teknik Mnegukur Kualitas Produk jasa. Kajian Bisnis Dan Manajemen Strategi, Sinergi. $V$.

Tjiptono, F. (2002). Strategi Pemasaran. Yogyakarta: Andi.

Tjiptono, F. (2005). Pemasaran Jasa. Malang: Bayumedia Publishing.

Tjiptono, F. (2008). Strategi Pemasaran (3rd ed.). Yogyakarta: Andi.

Toriq, Mochammad dan Martoatmodjo, S. (2014). PENGARUH FASILITAS DAN KUALITAS

LAYANAN TERHADAP KEPUASAN PADA SPBU PERTAMINA 54.612.64 DI SIDOARJO, 3(8).

Wanda, K. W. (2015). PENGARUH HARGA DAN PELAYANAN TERHADAP KEPUTUSAN PEMBELIAN DI MINI MARKET LULU MART SAMARINDA, 3(4), 757-768. 